\title{
Relationship between salivary shedding and seropositivity for Kaposi's sarcoma-associated herpesvirus (KSHV) and Epstein-Barr virus (EBV) among South African children and adults: insights on why EBV infection is ubiquitous and $\mathrm{KSHV}$ is not
}

\author{
Lisa Butler ${ }^{1 *}$, Sheila Dollard², Minal Amin², Anisa Mosam³ ${ }^{3}$ Jeffrey Martin ${ }^{1}$ \\ From $12^{\text {th }}$ International Conference on Malignancies in AIDS and Other Acquired Immunodeficiencies \\ (ICMAOI) \\ Bethesda, MD, USA. 26-27 April, 2010
}

\section{Background}

In a recent population-based study of South African children, we found KSHV seroprevalence in children to be low (7\%) and not associated with age, but EBV infection was nearly ubiquitous (96\%). While saliva is known to be the main conduit for transmission of both KSHV and EBV, little is known about the comparative patterns of KSHV and EBV salivary shedding in Africa. To address whether differences in salivary shedding may account for the difference in seroprevalence, we assessed KSHV and EBV shedding in children and their caregivers in South Africa.

\section{Methods}

Participants were children ages 1.5 to 8.9 years and their primary female caregivers in a population-based sample in a rural and an urban community in KwaZulu-Natal Province, South Africa. KSHV antibody testing utilized a previously established algorithm featuring two enzyme immunoassays and one indirect immunofluorescence assay. Viral DNA in unstimulated saliva was detected by PCR targeting ORF25 for KSHV and the EBNA gene for EBV.

\footnotetext{
*Correspondence: Ibutler@psg.ucsf.edu

'Department of Epidemiology and Biostatistics, University of California,

San Francisco, San Francisco, CA, USA

Full list of author information is available at the end of the article
}

\section{Results}

Among 458 children, 33 (7\%) were KSHV antibodypositive, of whom 30 had saliva available for testing. Of these $30,70 \%$ were female, and median age was 4.3 years (IQR 2.5-8.2). Among the female caregivers, 84 (17\%) were KSHV antibody-positive, of whom 80 had saliva available for testing. Of these 80 , the median age was 34 years (IQR 26-51). Among KSHV-seropositive individuals, KSHV DNA was detected in saliva of $1 / 30$ children $(3.3 \%)$ and $9 / 80(11.3 \%)$ adults $(\mathrm{p}=0.20)$. KSHV DNA was not detected in the saliva of any KSHV antibody-negative or -equivocal individual. EBV DNA was detected in the saliva of $83 \%(25 / 30)$ of children ( $\mathrm{p}<0.001$ compared to KSHV) and $60 \%(48 / 80)$ of adults $(\mathrm{p}<0.001$ compared to KSHV). There was no association between viral shedding of EBV and KSHV in saliva $(\mathrm{p}=0.83)$. Examination of the determinants of salivary shedding found that both younger age (odds ratio $=0.97$ per year of age, $\mathrm{p}=0.01)$ and HIV infection $(\mathrm{OR}=4.0$, $\mathrm{p}=0.01$ ) were independently associated with EBV shedding but not with KSHV shedding.

\section{Conclusions}

EBV is present in saliva substantially more often than KSHV among KSHV/EBV-infected South African children and adults. The much higher prevalence of EBV in saliva may, at least in part, explain why EBV infection is 
ubiquitous and KSHV is not. Attention next needs to turn to comparative mechanisms of host control of viral salivary shedding. The effect of HIV on herpesvirus salivary shedding suggests yet another reason why widespread therapy of HIV infection would be useful.

\section{Acknowledgements}

This article has been published as part of Infectious Agents and Cancer Volume 5 Supplement 1, 2010: Proceedings of the $12^{\text {th }}$ International Conference on Malignancies in AIDS and Other Acquired Immunodeficiencies (ICMAOI). The full contents of the supplement are available online at http://www.biomedcentral.com/1750-9378/5?issue=S1.

\section{Author details}

'Department of Epidemiology and Biostatistics, University of California, San Francisco, San Francisco, CA, USA. ${ }^{2}$ Centers for Disease Control and Prevention, Atlanta, GA, USA. ${ }^{3}$ University of KwaZulu-Natal, Durban, South Africa.

Published: 11 October 2010

doi:10.1186/1750-9378-5-S1-A69

Cite this article as: Butler et al:: Relationship between salivary shedding and seropositivity for Kaposi's sarcoma-associated herpesvirus (KSHV) and Epstein-Barr virus (EBV) among South African children and adults: insights on why EBV infection is ubiquitous and KSHV is not. Infectious Agents and Cancer 2010 5(Suppl 1):A69.

\section{Submit your next manuscript to BioMed Central} and take full advantage of:

- Convenient online submission

- Thorough peer review

- No space constraints or color figure charges

- Immediate publication on acceptance

- Inclusion in PubMed, CAS, Scopus and Google Scholar

- Research which is freely available for redistribution

Submit your manuscript at www.biomedcentral.com/submit 